Egyptian Journal of Aquatic Biology \& Fisheries

Zoology Department, Faculty of Science,

Ain Shams University, Cairo, Egypt.

ISSN 1110 - 6131

Vol. 22(5): 351- 361 (2018)

ejabf.journals.ekb.eg

\title{
Production and quality evaluation of hot smoked grass carp (Ctenopharyngodon idella) fillets stored at $4 \pm 1^{\circ} \mathrm{C}$
}

\author{
Sabri M. A. Shehata ${ }^{1}$, Abdelrahman S.A. Talab ${ }^{2}$, Mohammed H. M. Ghanem ${ }^{1}$ \\ and Mahmoud M. M. Abbas ${ }^{*}$ \\ 1- Marine Biology Branch, Zoology Department, Faculty of Science, Al-Azhar \\ University, Cairo, Egypt. \\ 2- Fish Processing and Technology Laboratory, Fisheries Division, National \\ Institute of Oceanography and Fisheries (NIOF), Cairo, Egypt. \\ * Crossponding Auher: Mahmoud_Mahrous42@yahoo.com, 00201064303459.
}

\section{ARTICLE INFO}

Article History:

Received: Nov.2,2018

Accepted:Dec.9, 2018

Online: Dec.15, 2018

\section{Keywords:}

Grass carp

hot smoking

chemical composition

heavy metals

sensory evaluation

\section{ABSTRACT}

The present study assessed the effect of hot smoke at $50-90^{\circ} \mathrm{C}$ for $5-6 \mathrm{~h}$ using hard sawdust of beech wood and two salt levels (10\% and $16 \%)$ on keeping quality of grass carp, Ctenopharyngodon idella, fillets stored at $4 \pm 1^{\circ} \mathrm{C}$. Chemical composition, physiochemical aspects, minerals and sensory analysis were determined.

Results showed that, the mean values of moisture, proteins, lipids, carbohydrates, ash, calorific value, $\mathrm{pH}, \mathrm{TVBN}$ and TBA were $78.11 \pm 0.69$, $16.55 \pm 0.84, \quad 2.31 \pm 0.01, \quad 1.16 \pm 0.01, \quad 1.87 \pm 0.01, \quad 91.63 \pm 1.49, \quad 6.55 \pm 0.01$, $4.43 \pm 0.05$ and $0.43 \pm 0.01$, respectively for raw grass carp; while it was recorded $48.22 \pm 0.23, \quad 23.38 \pm 0.18, \quad 13.88 \pm 0.11, \quad 8.14 \pm 0.01,6.38 \pm 0.09$, $251.05 \pm 1.33,6.15 \pm 0.05,12.42 \pm 0.03$ and $2.54 \pm 0.05$, respectively for hot smoked grass carp fillets with $10 \%$ salt concentrations and $48.01 \pm 0.23$, $23.01 \pm 0.18, \quad 14.66 \pm 0.17,5.41 \pm 0.03,8.50 \pm 0.03,247.27 \pm 2.22,5.52 \pm 0.03$, $8.88 \pm 0.02,2.04 \pm 0.07$, for the hot smoked grass carp fillets with $16 \%$ salt concentrations, respectively. Mean values of the tested minerals and heavy metals (mg/100g, on dry weight basis) of raw; hot smoked fillets with $10 \%$ and $16 \%$ salt concentrations were as follows: Ca $(170 \pm 0.27,233 \pm 1.11$, $236 \pm 1.21)$; K $(197 \pm 0.26,349 \pm 3.01,448 \pm 4.55), P(187 \pm 0.12,343 \pm 3.33$, $375 \pm 4.88)$, Na $(93.80 \pm 0.35,103 \pm 12.76,115 \pm 12.77)$, Cd $(0.07 \pm 0.001$, $0.023 \pm 0.001,0.020 \pm 0.001) ; \mathrm{Cu}(1.33 \pm 0.01,2.46 \pm 0.01,3.46 \pm 0.04) ; \mathrm{Fe}$ (25.15 $\pm 0.47, \quad 60.87 \pm 0.21, \quad 69.23 \pm 1.31) ; \quad$ Mn (0.98 $\pm 0.01, \quad 0.78 \pm 0.001$, $0.76 \pm 0.02)$; Ni $(0.64 \pm 0.003,0.77 \pm 0.001,0.60 \pm 0.001)$ and $\mathrm{Zn}(9.92 \pm 0.51$, $24.38 \pm 0.04$, 18.80 \pm 0.05$)$, respectively. Statistical analyses showed that, moisture, $\mathrm{pH}$ value, TVBN and TBA were significantly increased with the increasing storage time, while, proteins, lipids and ash were significantly decreased. Physicochemical aspects and sensory scores showed that, 16\% salted hot smoked fish was better than $10 \%$ with prolong the shelf life of hot smoked grass carp to 40 days of cold storage.

\section{INTRODUCTION}

Fish smoking is the oldest known preservation methods for centuries. It extends the shelf-life of fish and gives it the special color and flavor as a result of 
dehydration, antimicrobial and antioxidant of the smoke compounds and it is also changes the texture of product (Huong, 2013).

Smoked fish are divided according to processing temperature cold-smoked (at 30- $40^{\circ} \mathrm{C}$ for $30-60$ minutes, the internal temperature of the fish usually does not exceed $35^{\circ} \mathrm{C}$ ) and hot-smoked (greater than $90^{\circ} \mathrm{C}$, the internal temperature of fish typically exceeds $60^{\circ} \mathrm{C}$ ), while as hot-smoking is the method employed in traditional fish smoking in many developing countries (MOFA, 1999 and UNDP, 2002).

Grass carp (Ctenopharyngodon idella) is one of the most important commercial freshwater species. The global aquaculture production of this fish was 5,537,794 tons in 2014, and it ranked first among principal aquaculture species (FAO, 2016). Previous studies concluded that salting, smoking, polyphenols and chitosan coating were effective in extending the shelf-life of grass carp (Salama \& Ibrahim, 2012; Sun et al., 2017; Wang et al., 2014; Yu et al., 2017 and Huang et al., 2018). However, few studies have investigated the effect of different salt concentrations on the quality of hot smoked grass carp fillets. Therefore, the study aimed to examine the effect of hot smoking using two different salt concentrations (10\% and 16\%) on the keeping quality of grass carp, C. idella, fillets during cold storage as assessed by determination of chemical composition, physiochemical aspects, minerals, heavy metals and sensory analysis.

\section{MATERIALS AND METHODS}

\section{Fish samples:}

$40 \mathrm{~kg}$ of fresh grass carp (mean weight of $1291.39 \pm 12.23 \mathrm{~g}$ and mean length of $41.37 \pm 4.04 \mathrm{~cm}$ ) were bought from El-Obour City fish market. They were carefully washed with potable water, packed in ice boxes and transported to Fish Processing and Technology Laboratory, National Institute of Oceanography and Fisheries, ElKanater El-Khiria City, Egypt within 2 h. In the laboratory, fish samples were rewashed thoroughly with potable water, scaled, beheaded, gutted, filleted and rewashed immediately and drained.

\section{Brining:}

Commercial salt was used in the preparation of brine. The fish were divided into two groups; the first group was brined in $10 \% \mathrm{NaC} 1$ solution for $2 \mathrm{~h}$ at room temperature, while the second one was brined in $16 \% \mathrm{NaC} 1$ solution for the same period and the same temperature. The weight of fish and brine were equal for both methods of brining.

\section{Desalting and drying:}

The desalting process was carried out by immersing the brined fish fillets in water for $10 \mathrm{~min}$. then they were subjected to partial sun-drying temperatures fluctuated between $21^{\circ} \mathrm{C}$ and $28^{\circ} \mathrm{C}$ for two hours.

\section{Smoking:}

Fish samples were subjected for hot smoking using the hard sawdust of beech wood in a laboratory smokehouse at Shakshouk Research Station, El-Fayoum Governorate. Metal boarded plate was used above the smoke source by $75 \mathrm{~cm}$ to filtrate of smoke. Fish fillets were hooked above the smoke source by about $150 \mathrm{~cm}$. Hot smoking process was continued for $5-6 \mathrm{~h}$ at $50-90^{\circ} \mathrm{C}$. The smoking time, temperature and ambient conditions were monitored using a thermometer during the smoking operation. After smoking, samples were allowed to cool at ambient temperature and packaged in air tight polythene bags and kept in perforated plastic containers and stored at $\pm 4^{\circ} \mathrm{C}$ till the onset of spoilage by panel test. Chemical 
composition, physiochemical aspects, minerals, heavy metals and sensory analysis were carried out immediately after smoking and every ten days of storage.

\section{Analyses:}

Moisture, protein, lipids and ash were determined according to the methods described by AOAC, (2012). The $\mathrm{pH}$ value was done by the method of Goulas et al. (2005) using pH meter (HANNA, pH213). Total volatile bases nitrogen (TVBN) was done according to Mwansyemela (1973). Thiobarbituric acid (TBA) value was determined by the distillation method outlined by Tarladgis, et al., (1960). Magnesium (Mg), calcium (Ca), sodium ( $\mathrm{Na}$ ), potassium $(\mathrm{K})$, phosphor $(\mathrm{P})$, copper $(\mathrm{Cu})$, iron $(\mathrm{Fe})$, manganese $(\mathrm{Mn})$ and zinc $(\mathrm{Zn})$ contents were analyzed using an inductively coupled plasma optical emission spectrophotometer (ICP-OES) (Model 4300 DV, Perkin Elmer, Shelton, CT, USA) according to AOAC (1999). Organoleptic evaluation was performed according to the method suggested by Twig et al., (1976). Results were expressed as mean \pm SD. using SPSS 20, statistical software. Data were subjected to analysis of variance (ANOVA).

\section{RESULTS AND DISCUSSION}

\section{Chemical composition}

Chemical composition (on wet weight basis) of raw and hot smoked grass carp fillets are shown in Table (1). Data showed that, mean values of moisture, proteins, lipids, ash, carbohydrates and calorific value of raw fillets and hot smoked fillets treated with $10 \%$ and $16 \%$ salt concentrations were as follows: $78.11 \pm 0.69$, $16.55 \pm 0.84,2.31 \pm 0.01,1.87 \pm 0.01,1.16 \pm 0.01,91.63 \pm 1.49 ; 48.22 \pm 0.23,23.38 \pm 0.18$, $13.88 \pm 0.11, \quad 6.38 \pm 0.09, \quad 8.14 \pm 0.01, \quad 251.05 \pm 1.33$ and $48.01 \pm 0.23, \quad 23.38 \pm 0.18$, $14.66 \pm 0.17,8.50 \pm 0.03,5.41 \pm 0.03,247.27 \pm 2.22$, respectively. Similar observations were agreed with Salama \& Ibrahim, 2012 and Haq et al., 2013.

Table 1: Chemical composition (on wet weight basis) of raw and hot smoked grass carp fillets.

\begin{tabular}{|l|c|c|c|}
\hline \multirow{2}{*}{ Constitutes } & \multirow{2}{*}{ Raw grass carp } & \multicolumn{2}{c|}{ Smoked grass carp } \\
\cline { 3 - 4 } & & $10 \%$ salt & $16 \%$ salt \\
\hline Moisture (\%) & $78.11 \pm 0.69$ & $48.22 \pm 0.23$ & $48.01 \pm 0.23$ \\
\hline Protein (\%) & $16.55 \pm 0.84$ & $23.38 \pm 0.18$ & $23.38 \pm 0.18$ \\
\hline Lipids (\%) & $2.31 \pm 0.01$ & $13.88 \pm 0.11$ & $14.66 \pm 0.17$ \\
\hline Ash (\%) & $1.87 \pm 0.01$ & $6.38 \pm 0.09$ & $8.50 \pm 0.03$ \\
\hline Carbohydrates (\%) & $1.16 \pm 0.01$ & $8.14 \pm 0.01$ & $5.41 \pm 0.03$ \\
\hline Calorific value (kcal/100 g) & $91.63 \pm 1.49$ & $251.05 \pm 1.33$ & $247.27 \pm 2.22$ \\
\hline
\end{tabular}

\section{Physicochemical quality criteria}

The mean values of physicochemical aspects of raw and hot smoked grass carp fillets treated with $10 \%$ and $16 \%$ salt concentrations were as follows: $\mathrm{pH}$ value (6.55 $\pm 0.01,6.15 \pm 0.05, \quad 5.52 \pm 0.03)$; TVBN $(4.43 \pm 0.05, \quad 12.42 \pm 0.03, \quad 8.88 \pm 0.02$ $\mathrm{mg} / 100 \mathrm{~g})$ and TBA $(0.43 \pm 0.01,2.54 \pm 0.05,2.04 \pm 0.07 \mathrm{mg} \mathrm{MDA} / \mathrm{kg})$, on wet weight basis, respectively (Table 2). Similar observations were detected by Morzel \& van de Vis (2003) and Xiao et al. (2000).

Table 2: Physical and chemical properties (on wet weight basis) of raw and hot smoked grass carp fillets.

\begin{tabular}{|l|c|c|c|}
\hline \multirow{2}{*}{ Parameter } & \multirow{2}{*}{ Raw grass carp } & \multicolumn{2}{c|}{ Smoked grass carp fillets } \\
\cline { 3 - 4 } & & $10 \%$ salt & $16 \%$ salt \\
\hline pH value & $6.55 \pm 0.01$ & $6.15 \pm 0.05$ & $5.52 \pm 0.03$ \\
\hline TVB-N (mg/100g) & $4.43 \pm 0.05$ & $12.42 \pm 0.03$ & $8.88 \pm 0.02$ \\
\hline TBA (mg MDA/kg) & $0.43 \pm 0.01$ & $2.54 \pm 0.05$ & $2.04 \pm 0.07$ \\
\hline
\end{tabular}




\section{Mineral contents:}

The mean values of the tested minerals (mg/100g, on dry weight basis) of the raw; hot smoked grass carp fillets (with $10 \%$ and 16\%) salt concentrations were as follows: Ca (170 $\pm 0.27,233 \pm 1.11$, 236 \pm 1.21$)$; $\mathrm{K}$ : $(197 \pm 0.26,349 \pm 3.01,448 \pm 4.55)$, P:

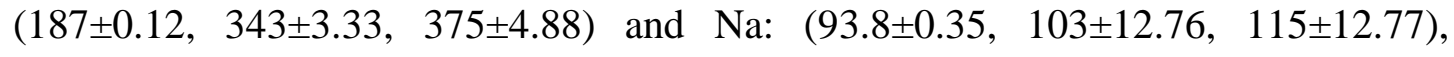
respectively (Table 3) Similar observations were recorded by Eyo (2001).

Table 3: Minerals concentrations (mg/100g, on dry weight basis) of raw and hot smoked grass carp fillets

\begin{tabular}{|c|c|c|c|}
\hline \multirow{2}{*}{ Elements } & \multirow{2}{*}{ Raw grass carp } & \multicolumn{2}{|c|}{ Smoked grass carp } \\
\cline { 3 - 4 } & & $10 \%$ salt & $16 \%$ salt \\
\hline $\mathrm{Ca}$ & $170 \pm 0.27^{\mathrm{a}}$ & $233 \pm 1.11^{\mathrm{b}}$ & $236 \pm 2.21^{\mathrm{c}}$ \\
\hline $\mathrm{K}$ & $197 \pm 0.26^{\mathrm{a}}$ & $349 \pm 3.01^{\mathrm{b}}$ & $448 \pm 4.55^{\mathrm{c}}$ \\
\hline $\mathrm{P}$ & $187 \pm 0.12^{\mathrm{a}}$ & $343 \pm 3.33^{\mathrm{b}}$ & $375 \pm 4.88^{\mathrm{c}}$ \\
\hline $\mathrm{Na}$ & $93.80 \pm 0.35^{\mathrm{a}}$ & $103 \pm 12.76^{\mathrm{b}}$ & $115 \pm 12.77^{\mathrm{c}}$ \\
\hline
\end{tabular}

\section{Heavy metals levels:}

The mean values of the tested heavy metals (mg/100g, on dry weight basis) of raw and hot smoked grass carp fillets treated with $10 \%$ and $16 \%$ salt concentrations were as follows: $\mathrm{Cd}(0.07 \pm 0.001,0.023 \pm 0.001,0.020 \pm 0.001)$; $\mathrm{Cu}(1.33 \pm 0.01$, $2.46 \pm 0.01,3.46 \pm 0.04)$; Fe (25.15 $\pm 0.47,60.87 \pm 0.21,69.23 \pm 1.31)$; Mn (0.98 \pm 0.01 , $0.78 \pm 0.03, \quad 0.76 \pm 0.02) ; \mathrm{Ni}(0.64 \pm 0.003, \quad 0.773 \pm 0.001,0.600 \pm 0.001)$ and $\mathrm{Zn}$ $(9.92 \pm 0.51,24.383 \pm 0.04,18.80 \pm 0.05)$, respectively, (Table 4). Similar observations were recorded by Jayaprakash et al. (2015) and Leung et al. (2014).

Table 4: Heavy metals concentrations (mg/100g, on dry weight basis) of raw and hot smoked grass carp fillets

\begin{tabular}{|c|c|c|c|}
\hline \multirow{2}{*}{ Metals } & \multirow{2}{*}{ Raw grass carp } & \multicolumn{2}{|c|}{ Smoked grass carp } \\
\cline { 3 - 4 } & & $10 \%$ salt & $16 \%$ salt \\
\hline $\mathrm{Cd}$ & $0.07 \pm 0.001^{\mathrm{a}}$ & $0.023 \pm 0.001^{\mathrm{b}}$ & $0.020 \pm 0.001^{\mathrm{c}}$ \\
\hline $\mathrm{Cu}$ & $1.33 \pm 0.01^{\mathrm{a}}$ & $2.46 \pm 0.01^{\mathrm{b}}$ & $3.46 \pm 0.04^{\mathrm{c}}$ \\
\hline $\mathrm{Fe}$ & $25.15 \pm 0.47^{\mathrm{a}}$ & $60.87 \pm 0.21^{\mathrm{b}}$ & $69.23 \pm 1.31^{\mathrm{c}}$ \\
\hline $\mathrm{Mn}$ & $0.98 \pm 0.01^{\mathrm{a}}$ & $0.78 \pm 0.03^{\mathrm{b}}$ & $0.76 \pm 0.02^{\mathrm{b}}$ \\
\hline $\mathrm{Ni}$ & $0.64 \pm 0.003^{\mathrm{a}}$ & $0.77 \pm 0.001^{\mathrm{b}}$ & $0.60 \pm 0.001^{\mathrm{c}}$ \\
\hline $\mathrm{Zn}$ & $9.92 \pm 0.51^{\mathrm{a}}$ & $24.38 \pm 0.04^{\mathrm{b}}$ & $18.80 \pm 0.05^{\mathrm{c}}$ \\
\hline
\end{tabular}

\section{Changes in chemical composition and physicochemical quality of hot smoked grass carp fillets stored at $4 \pm 1^{\circ} \mathrm{C}$ : \\ Moisture content:}

The mean values of moisture content of hot smoked grass carp fillets with $10 \%$ and $16 \%$ salt concentration stored at $4 \pm 1^{\circ} \mathrm{C}$ were $48.22 \pm 0.23$ and $48.01 \pm 0.23$ at zero time of storage. They were $61.99 \pm 0.55$ and $59.45 \pm 0.34$ respectively, at the end of storage period (Figure 1). The obtained results disagree with Salama \&Ibrahim (2012) whom recoded that, the moisture contents of smoked grass carp were decreased during storage at $2 \pm 1^{\circ} \mathrm{C}$ for 30 days from 62.45 and 66.81 at zero time, to 60.50 and 64.71 at the end of cold storage. They attributed the decrease in moisture content to the exclusion of available water from the fish by the effect of different treatments salting, drying and smoking. 


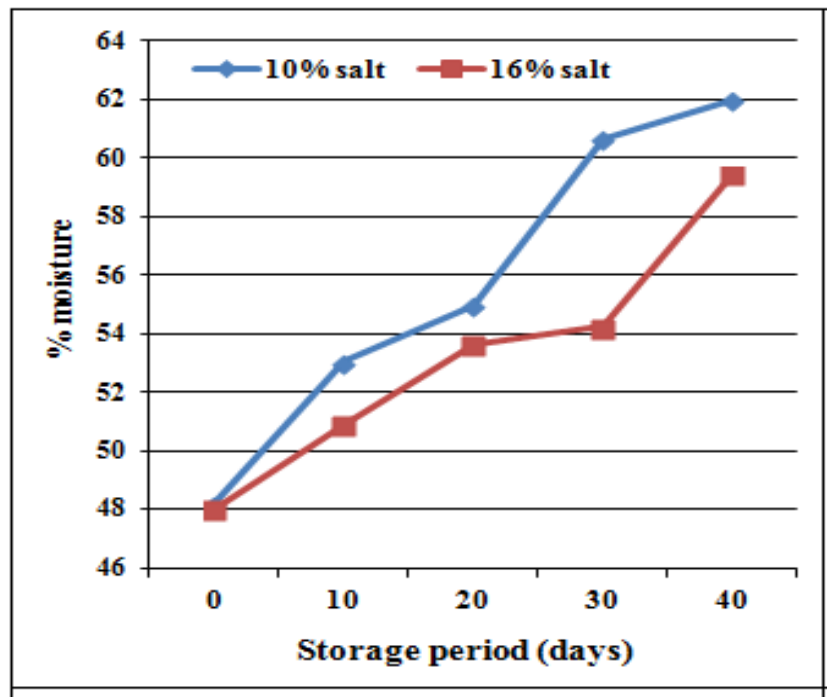

Fig. 1: Changes in moisture content (\%) of hot smoked grass carp fillets stored at $4 \pm 1^{\circ} \mathrm{C}$

\section{Crude protein content:}

The values of crude protein content of hot smoked grass carp fillets with $10 \%$ and $16 \%$ salt concentration stored at $4 \pm 1^{\circ} \mathrm{C}$ were, $23.38 \pm 0.18,23.38 \pm 0.18$ at zero time of storage; while they were $21.29 \pm 0.12,21.69 \pm 0.11$ respectively, at the end of storage period (Figure 2). Present study were in agreement with Salama \& Ibrahim (2012) whom concluded that, the crude protein contents of smoked grass carp were decreased during storage at $2 \pm 1^{\circ} \mathrm{C}$ for 30 days from $69.30 \pm 0.07$ and $70.01 \pm 0.06$ at zero time, to $67.78 \pm 0.06$ and $67.90 \pm 0.06$ at the end of cold storage. They attributed the decrease in crude protein content during cold storage of smoked grass carp to the decomposition and degradation of nitrogen substances which may be due to the activity of microorganisms and proteolytic enzymes.

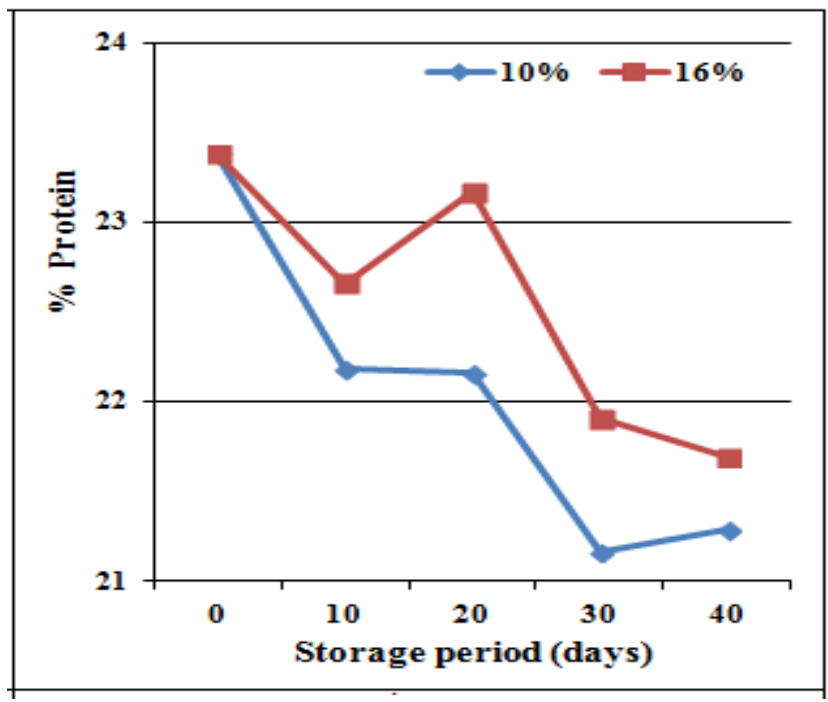

Fig. 2: Changes in protein content of hot smoked grass carp fillets stored at $4 \pm 1^{\circ} \mathrm{C}$

\section{Lipid content:}

The mean values of lipid content of hot smoked grass carp fillets treated with $10 \%$ and $16 \%$ salt concentrations stored at $4 \pm 1^{\circ} \mathrm{C}$ were $13.88 \pm 0.11$ and $14.66 \pm 0.17$ respectively at zero time of storage; while they were $10.62 \pm 0.14$ and $10.94 \pm 0.17$ 
respectively, at the end of storage period (Figure 3). These results coincide with those given by Salama \&Ibrahim (2012) whom reported that, the lipid contents of smoked grass carp were decreased during storage at $2 \pm 1^{\circ} \mathrm{C}$ for 30 days from $19.46 \pm 0.05$ and $20.31 \pm 0.06$ at zero time, to $18.68 \pm 0.06$ and $19.23 \pm 0.06$ at the end of cold storage. They attributed the decrease in lipid content during cold storage of smoked grass carp to the activity of microorganisms and lipolytic enzymes which lead to breakdown of fatty acids.

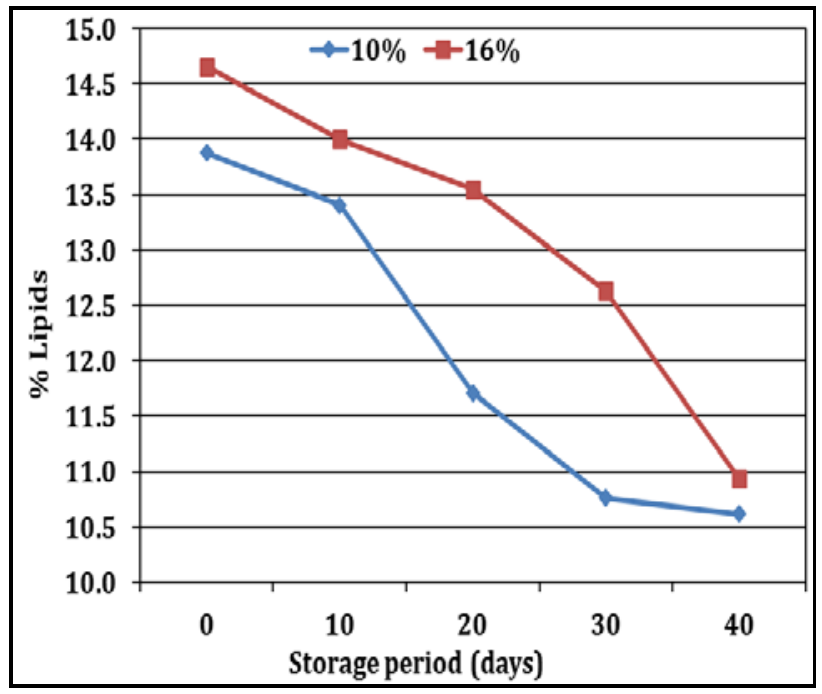

Fig. 3: Changes in lipid content of hot smoked grass carp fillets stored at $4 \pm 1^{\circ} \mathrm{C}$

\section{Ash content:}

The average values of ash content of hot smoked grass carp fillets treated with $10 \%$ and $16 \%$ salt concentrations and stored at $4 \pm 1^{\circ} \mathrm{C}$ at zero time were $6.38 \pm 0.09$, $8.50 \pm 0.03$, while they were $4.98 \pm 0.03,7.79 \pm 0.08$ respectively, at the end of storage period (Figure 4). The present results disagree with those given by Salama \&Ibrahim (2012) whom found that, ash contents of smoked grass carp were increased during storage at $2 \pm 1^{\circ} \mathrm{C}$ for 30 days from $11.20 \pm 0.04$ and $9.95 \pm 0.04$ at zero time, to $13.40 \pm$ 0.05 and $12.80 \pm 0.05$ at the end of cold storage. They attributed the increase in ash content during cold storage of smoked fish to the addition of salt.

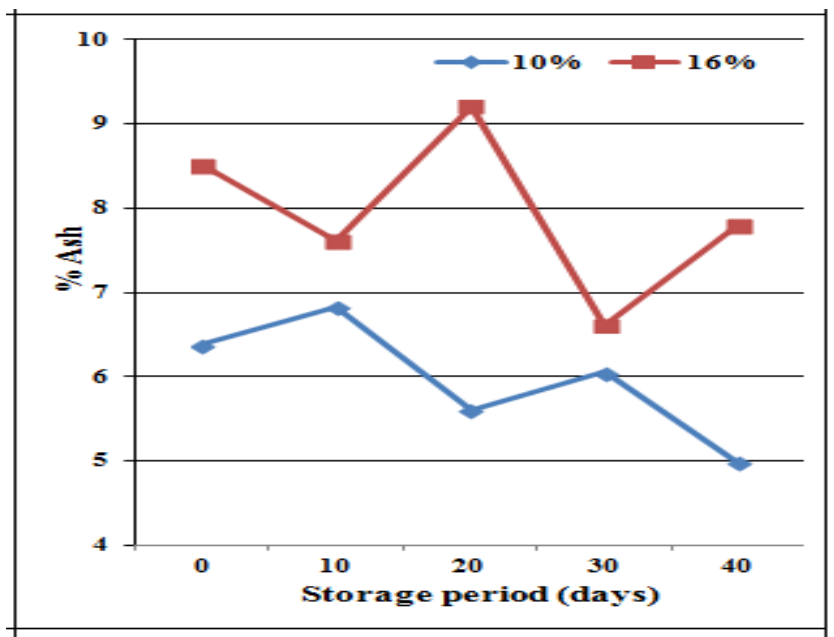

Fig. 4: Changes in ash content of hot smoked grass carp fillets stored at $4 \pm 1^{\circ} \mathrm{C}$

\section{pH value:}


$\mathrm{pH}$ values of hot smoked grass carp fillets treated with $10 \%$ and $16 \%$ salt concentrations and stored at $4 \pm 1^{\circ} \mathrm{C}$ at zero time were $6.15 \pm 0.05$ and $5.52 \pm 0.03$. They were $6.38 \pm 0.07$ and $6.33 \pm 0.02$ respectively, at the end of storage period (Figure 5). These results disagree with those given by Salama \& Ibrahim (2012) whom found that, $\mathrm{pH}$ value of smoked grass carp were decreased during storage at $2 \pm 1^{\circ} \mathrm{C}$ for 30 days from $6.6 \pm 0.03,6.2 \pm 0.04$, and $6.0 \pm 0.05$ at zero time, to $5.8 \pm 0.03,5.4 \pm 0.04$, and $5.1 \pm 0.05$ at the end of cold storage. They attributed the decline in $\mathrm{pH}$ value to the protein denaturation and fat autolysis which lead to the liberated amino acids, free fatty acids and lactic acid which may be produced in different amounts during the storage period. On the other hand, the decrease in $\mathrm{pH}$ may be attributed to the production of volatile basic components, such as ammonia, trimethylamine etc. by fish spoiling bacteria. Similar observation were detected by many authors including Bibek (1992); Reddy et al. (1997); Khallaf et al. (1997); Hyytia et al. (1999); Nykanen et al. (2000) and Ruiz-Capillas \& Moral, (2001).

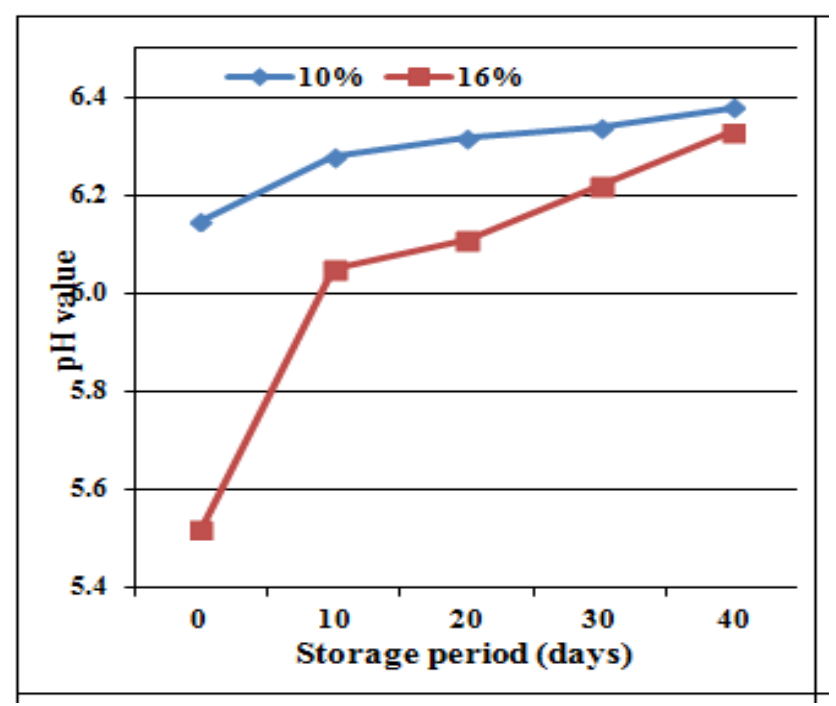

Fig. 5: Changes in $\mathrm{pH}$ value of hot smoked grass carp fillets stored at $4 \pm 1^{\circ} \mathrm{C}$

\section{Total volatile basic nitrogen (TVBN) content:}

The mean values of total volatile basic nitrogen (TVBN) of hot smoked fillets treated with $10 \%$ and $16 \%$ salt concentrations and stored at $4 \pm 1^{\circ} \mathrm{C}$ were $12.42 \pm 0.03$ and $8.88 \pm 0.02$, respectively at zero time of storage. They were $28.68 \pm 0.03$ and $22.39 \pm 0.05$ respectively, at the end of storage period (Figure 6). These results were in accordance with those given by Plahar et al. (1999) and Salama \& Ibrahim (2012) whom stated that, TVBN contents of smoked grass carp were increased during cold storage.

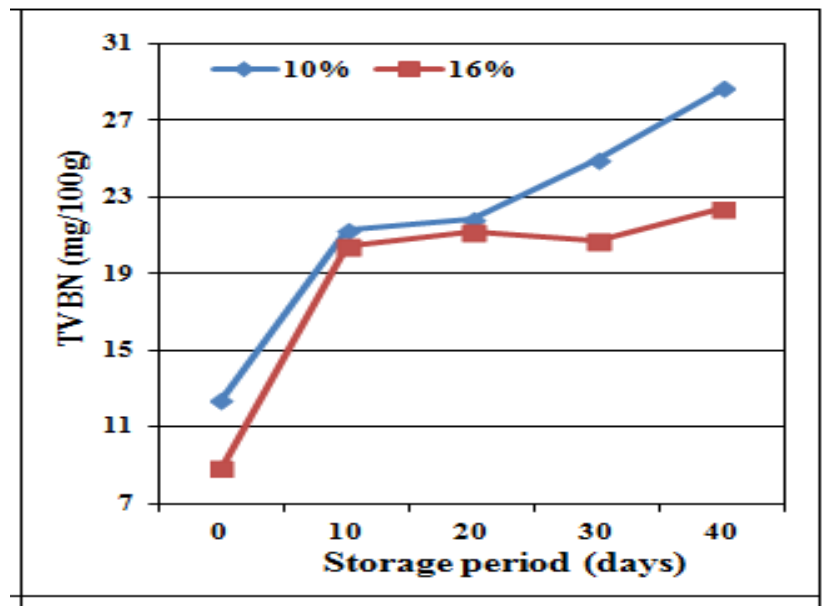


Fig. 6: Changes in total volatile basic nitrogen $(\mathrm{mg} / 100 \mathrm{~g}$,) of hot smoked grass carp fillets stored at $4 \pm 1^{\circ} \mathrm{C}$

\section{Thiobarbituric acid (TBA) value:}

The mean values of thiobarbituric acid (TBA) value of hot smoked grass carp fillets treated with $10 \%$ and $16 \%$ salt concentrations and stored at $4 \pm 1^{\circ} \mathrm{C}$ were $2.54 \pm 0.05$ and $2.04 \pm 0.07$, respectively at zero time of storage. They were $6.68 \pm 0.07$ and $5.70 \pm 0.03$ respectively, at the end of storage period (Figure 7). These results coincide with those given by Gomes et al. (2003) and Salama \& Ibrahim (2012).

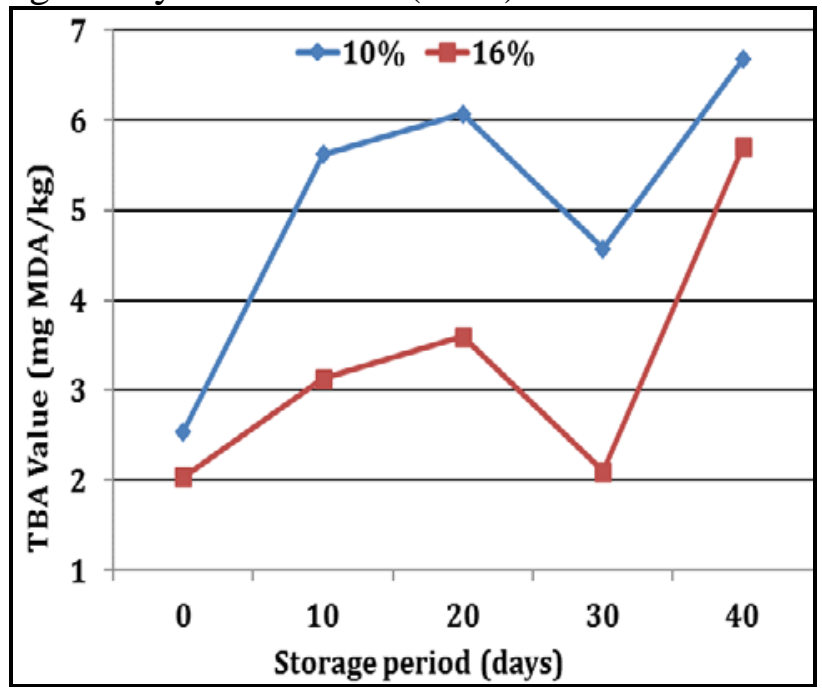

Fig. 7: Changes in thiobarbituric acid value (mg MDA $/ \mathrm{kg}$ ) of hot smoked grass carp fillets stored at $4 \pm 1^{\circ} \mathrm{C}$

\section{Sensory evaluation:}

The initial values of sensory scores (color, flavor, taste, tenderness, juiciness, overall acceptability scores of smoked grass carp treated with $10 \%$ and $16 \%$ salt concentration and stored at $4 \pm 1^{\circ} \mathrm{C}$ showed no negligible alternation after processing during zero time. However, $10 \%$ salted smoked grass carp showed very good scores (8.95) for color, pronounced scores (8.70) for flavor, very full scores (8.85) for taste, very tender scores (8.50) for tenderness, very juicy scores (8.25) for juiciness, very good scores (9.00) for overall acceptability immediately after processing during zero time. Moreover, the trial 16\% salted smoked fish showed very good scores (8.90) for color, pronounced scores (8.65) for flavor, very full scores (8.75) for taste, very tender scores (8.30) for tenderness, very juicy scores (8.35) for juiciness, very good scores (8.50) for overall acceptability immediately after processing at zero time with the slightly increase in salted taste. In general, a noticeable difference could be observed between smoked grass carp groups (10\% and 16\%) in the case of taste characteristic after processing during zero time.

During the storage time, the overall acceptability scores of two groups (10\% and $16 \%$ ) samples decreased from 8.80 and 8.50 during $10^{\text {th }}$ days of storage to reach its lowest score 3.25 and 4.55 during the end of storage ( $40^{\text {th }}$ days), respectively which was below the acceptable limit of score (5); thus the two groups (10\% and $16 \%$ ) become rejected for consumers after $40^{\text {th }}$ days of storage. 


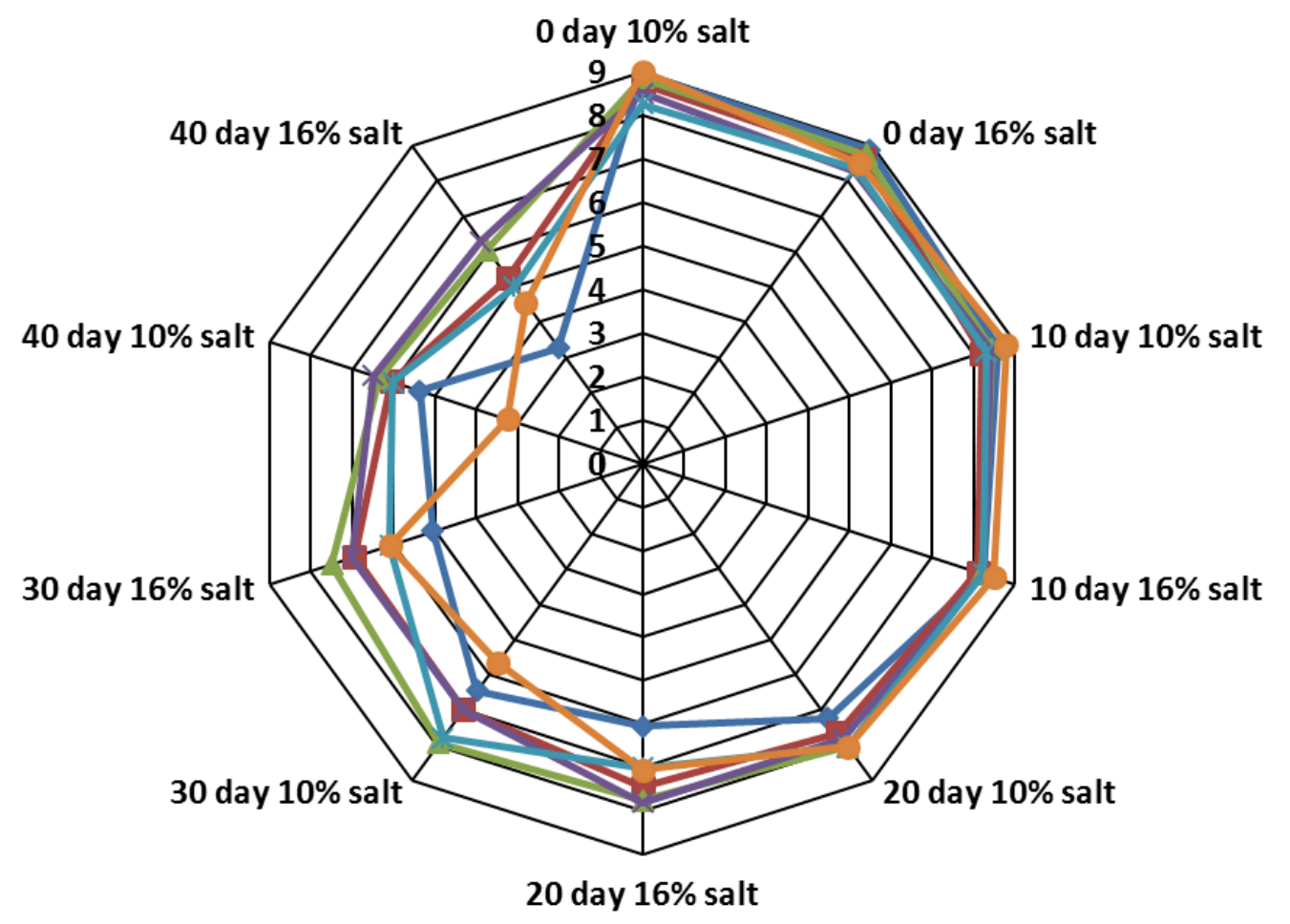

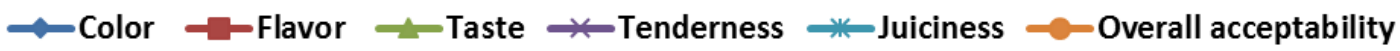

Fig. 8: Changes in sensory scores of hot smoked grass carp fillets stored at $4 \pm 1^{\circ} \mathrm{C}$.

\section{CONCLUSIONS}

From above findings, it can be concluded that, the hot smoking can be used for processing grass carp which led to the production of a high-quality delicatessen food item, which could be an alternative to cooked fresh fish. To the best of our knowledge this is one of the little studies of the shelf life of hot smoked grass carp. Based on the physicochemical analysis and sensory scores it can be illustrated that, $16 \%$ salted hot smoked grass carp was better than $10 \%$ with prolong the shelf life of hot smoked grass carp to 40 days of cold storage.

\section{REFERENCES}

AOAC (1999). Official Method of Analysis of AOAC Intl. $16^{\text {th }}$ ed. Association of Official Analytical Communities, Arlington, VA, USA.

AOAC (2012). Official methods of analysis. Association of Official Analytical Chemists, Inc., Washington, DC, USA.

Bibek, R. (1992). Nisin of lactococcus lactis ssp. Lactis as a food biopreservative. In food biopreservatives of microbial origin. Bibek, R and Daesechel ed., M. CRC Press, P: 209- 275.

Eyo, A.A. (2001). Fish processing technology in the tropics. Nigeria/Institute for fresh water Fishers Research (NIFFR), New Bussa, Nigeria. 
FAO (2016). FAO-Yearbook of Fishery Statistics: Aquaculture Production. Food and Agriculture Organization of the United Nations, Rome, pp. 30.

Gomes, H.A.; Silva, E.N.; Nascimento, M.R. and Fukuma, H.T. (2003). Evaluation of the 2thiobarbituric acid method for the measurement of lipid oxidation in mechanically deboned gamma irradiated chicken meat. Food Chemistry, 80: 433-437.

Goulas, A.E.; Chouliara, I.; Nessi, M.G.; Kontominas, M.G. and Savvaidis, V. (2005). Microbiological, biochemical and sensory assessment of (Mytilus galloprovincialis) stored under modified atmosphere packaging. Journal of Applied Microbiology, 98(3): $752-760$.

Haq, M.; Dutta, P.L.; Sultana, N and Rahman, M.A. (2013). Production and quality assessment of fish burger from the grass carp, Ctenopharyngodon idella (Cuvier and Valenciennes, 1844). Journal of Fisheries, 1(1): 42-47.

Huang Zhan, L.; Liu, X.; Jia, S.; Zhang, L. and Yongkang, L. (2018). The effect of essential oils on microbial composition and quality of grass carp (Ctenopharyngodon idella) fillets during chilled storage. International Journal of Food Microbiology, 266: 52-59.

Huong, D. (2013). The effect of smoking methods on the quality of smoked mackerel. Reykjavik: United Nations University - Fisheries Training Programme. Final Project.

Hyytia, E.; Hielm, S.; Mokkila, M.; Kinnunen, A. and Korkeala, H. (1999). Predicted and observed growth and toxigenesis by Clostridium botulinum type $\mathrm{E}$ in vacuumpackaged fishery products challenge tests. International Journal of Food Microbiology, 47: 161-169.

Jayaprakash, M., Kumar, R.S.; Giridharan, L.; Sujitha, S.B.; Sarkar, S. K. and Jonathan, M.P. (2015). Bioaccumulation of metals in fish species from water and sediments in macrotidal Ennore creek, Chennai, SE coast of India: A metropolitan city effect. Ecotoxicology and Environmental Safety, 120: 243-255.

Khallaf, M.F; El-Samkary, M.A; Ahmed, S.A. and Taleb, M. (1997). Chemical and bacteriological changes occurring during the processing of Egyptian sliver carp fish. Egypt J. Aquat. Biol., 1 (2): 53-70.

Leung, H.M.; Leung, A.O.W.; Wang, H.S.; Ma, K.K.; Liang, Y.; Ho, K.C.; ... and Yung, K.K.L. (2014). Assessment of heavy metals/metalloid (As, Pb, Cd, Ni, Zn, Cr, Cu, $\mathrm{Mn})$ concentrations in edible fish species tissue in the Pearl River Delta (PRD), China. Marine Pollution Bulletin, 78(1-2): 235-245.

MOFA, Ministry of Food and Agriculture, Ghana (1999). A manual on training agricultural extension agents in fish processing. Fish Processing and Marketing Section, Fisheries Directorate, MOFA, Accra, Ghana.

Morzel, M. and Van de vis, H. (2003). Effect of the slaughter method on the quality of raw and smoked eels (Anguilla anguilla L.). Aquac. Res., 34: 1-11.

Mwansyemela, N.A. (1973). Report on studies of routine analysis for food chemistry. The Institute for Fisher Products TNO at Ijmuiden Holland.

Nykanen, A.; Weckman, K. and Lapvetelainen, A. (2000). Synergistic inhibition of listeria monocytogenes on cold-smoked rainbow trout by nisin and sodium lactate. International Journal of Food Microbiology, 61 (1): 63-72.

Plahar, W.A.; NerquayeTetteh, G.A. and Annan, N.T. (1999). Development of an integrated quality assurance system for the traditional Sardinella sp. and anchovy fish smoking industry in Ghana. Food Control, 10: 15- 25.

Reddy, N.R.; Roman, M.G.; Villanueva, M.; Solomon, H.M.; Kautter, D.A. and Rhodehamel, E.J. (1997). Shelf life and Clostridium botulinum toxin development during storage of modified atmosphere-packed fresh catfish fillets. Journal of Food Science, 62 (4): 878-884.

Ruiz-Capillas, C. and Moral, A. (2001a). Residual effect of $\mathrm{CO}_{2}$ on hake (Merluccius merluccius L.) stored in modified and controlled atmospheres. European Food Research and Technology, 212: 413-420.

Salama M.I. and Ibrahim A.E.E. (2012). Changes in the quality properties of Grass Carp (Ctenopharyngodon Idella) fillets smoked during Chilled storage. Journal of the Arabian Aquaculture Society, 7(2): 165-184. 
Sun, L.; Sun, J.; Thavaraj, P.; Yang, X.; and Guo, Y., (2017). Effects of thinned young apple polyphenols on the quality of grass carp (Ctenopharyngodon idella) surimi during cold storage. Food Chem., 224: 372-381.

Tarladgis, B.G.; Watts, B.M. and Yonathan, M. (1960). Distillation method for the determination of malonaldehyde in rancid foods. J. of American Oil Chemistry Society, 37(1): 44-48.

Twig, G.; Your, E.P.; and Kitul, A.W. (1976). Evaluation of beef patties containing soy protein during 12 month frozen storage. Food Science., 41: 1142-1147.

UNDP (2002). Fish smoking with the Chorkor smoker: Ghana. http:www.undp.org/tcdc/bestprac/agri/cases/ghana15/html.

Wang, H.; Luo, Y.; Yin, X.; Wu, H.; Bao, Y. and Hong, H. (2014). Effects of salt concentration on biogenic amine formation and quality changes in grass carp (Ctenopharyngodon idella) fillets stored at 4 and $20^{\circ} \mathrm{C}$. J. Food Prot., 77: 796-804.

Xiao, D.Y.; Liu, J.B.; Chen, Q.H.; Jin, H.; Fu, W.D. and Chen, K.J. (2004). Analysis of nutritious traits of crisp grass carp (Ctenopharyngodon idellus $C$. et V). Reservoir Fish. China, 34(3): 28-30.

Yu, D.; Li, P.; Xu, Y.; Jiang, Q. and Xia, W. (2017). Physicochemical, microbiological, and sensory attributes of chitosan-coated grass carp, Ctenopharyngodon idella, fillets stored at $4{ }^{\circ} \mathrm{C}$. Int. J. Food Prop., 2: 390-401.

\section{ARABIC SUMMARY}

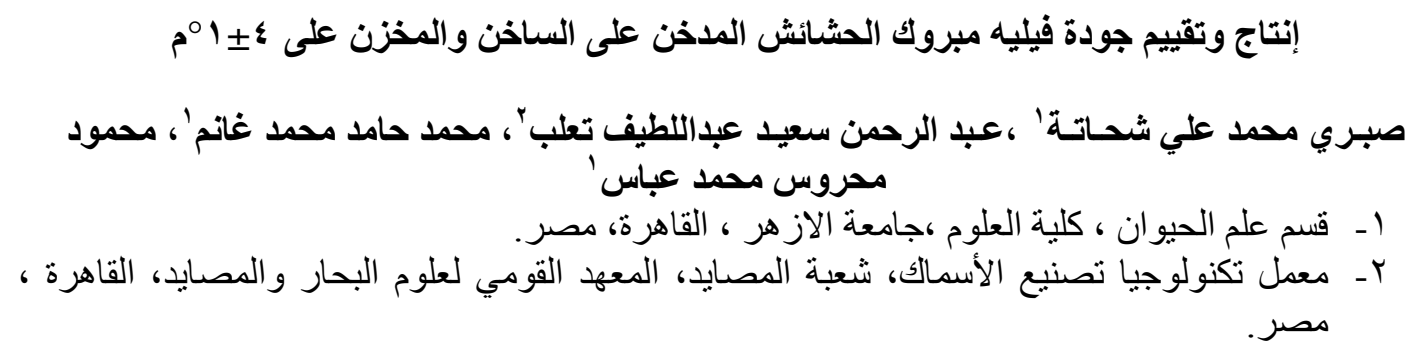

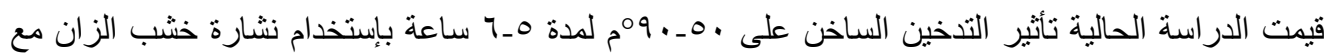

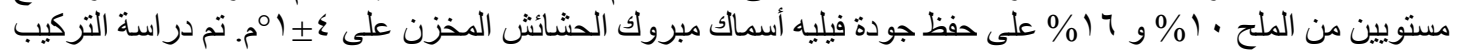

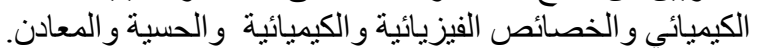

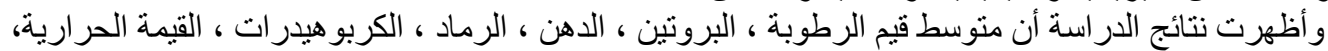

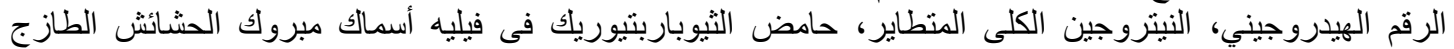

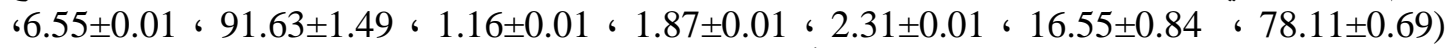

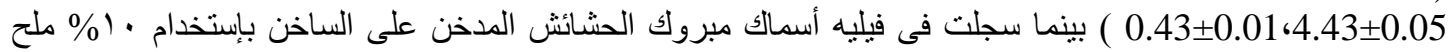

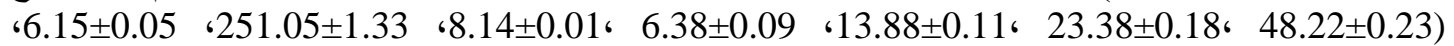

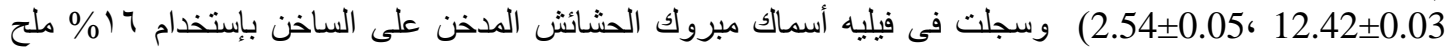

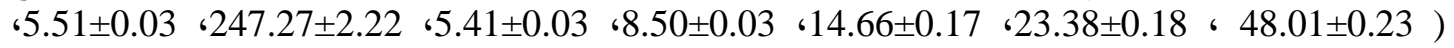

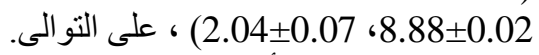

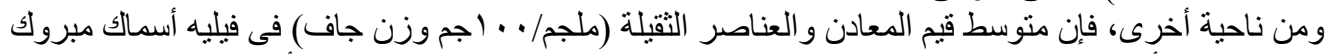

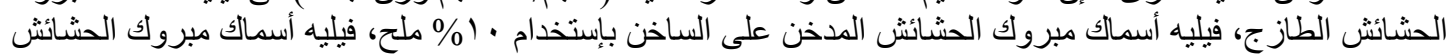

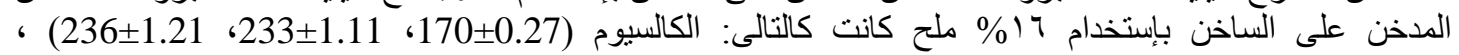

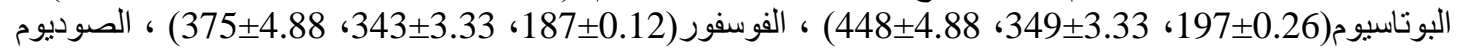

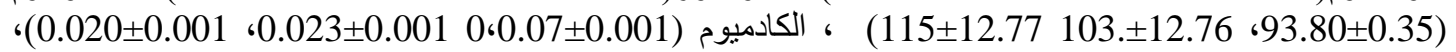

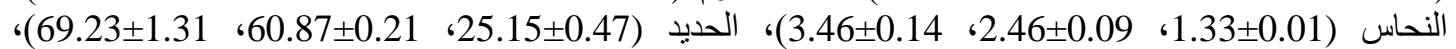

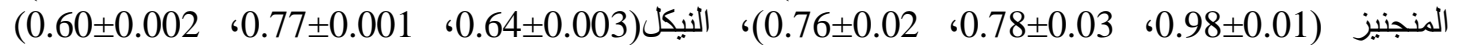

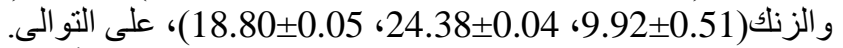

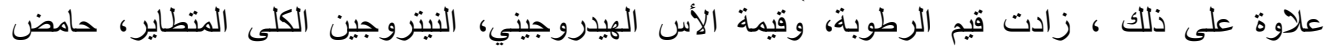

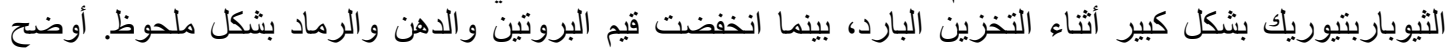

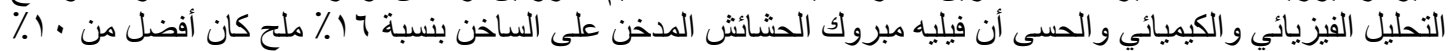

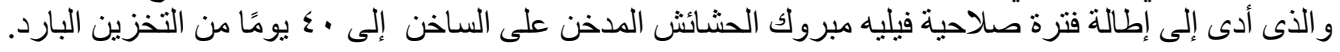

